\title{
鹿児島県内の農耕地土壤におけるウランの蓄積実態
}

\author{
赤木 功, 橒木 直也 \\ 鹿児島大学 農学部（下890-0065 鹿児島県鹿児島市郡元1-21-24）
}

[2020年 3 月30日受付, 2020 年 8 月 4 日受理］

\section{The Accumulation of Uranium in Agricultural Soils in Kagoshima Prefecture, Japan}

\author{
Isao AKAGI and Naoya CHISHAKI
}

Faculty of Agriculture, Kagoshima University

(1-21-24 Korimoto, Kagoshima, Kagoshima 890-0065)

[Received March 30, 2020; Accepted August 4, 2020]

\begin{abstract}
Summary
The uranium (U) concentrations of the agricultural and non-agricultural soils in four areas (Isa, Nagashima, Nansatsu, and Osumi) in Kagoshima Prefecture were determined. The U concentrations of the agricultural soils were higher than those of the non-agricultural soils in all areas. The $\mathrm{U}$ concentrations were positively correlated with the $\mathrm{P}$ concentrations in the soils, which suggested a link between long-term phosphate fertilizer application and $\mathrm{U}$ accumulation in the soils. The amounts of $U$ enriched in the agricultural soil surfaces $(0-15 \mathrm{~cm}$ depth) in the Isa, Nagashima, Nansatsu, and Osumi areas, as calculated from the comparison with the non-agricultural soils, were estimated to be 47-318, 25-343, 61-226, and $47-185 \mathrm{mg} / \mathrm{m}^{2}$, respectively. This demonstrated that the accumulation of $\mathrm{U}$ occurred in the agricultural soils in these areas. The commercially available superphosphate, magnesium multi-phosphate, fused magnesium phosphate, animal waste composts, and sewage sludge compost in these areas contained 51.6, 22.2, 10.6, 0.88-1.07, and $1.56 \mu \mathrm{g} /$ $\mathrm{g}$ of $\mathrm{U}$, respectively, which showed that these fertilizer materials could become sources of $\mathrm{U}$ in agricultural soils. According to the calculation with reference to the amount of fertilizer applied, it was estimated that the amounts of $U$ added from fertilizers were $2.7-3.0 \mathrm{mg} / \mathrm{m}^{2}$ in rice paddy fields and $8.6-9.2 \mathrm{mg} / \mathrm{m}^{2}$ in Chinese cabbage fields per cropping system. These results indicated that the amounts of $U$ input derived from fertilizers per cropping system differed greatly depending on the cultivated crop.
\end{abstract}

Key words: agricultural soils, fertilizers, uranium

\section{1. はじめに}

ウラン（U） は化学毒性を有する重金属の一つとして知られてお り，その摂取により腎障害を引き起こすことが実験動物を用いた毒 性試験によって確かめられている ${ }^{1-3)}$ 。世界保健機構（WHO）は, 1998年に飲料水のUに関して健康に基づく暫定ガイドライン值を設 定し, 最新の “Guidelines for drinking-water quality 4th ed.”におい てその值を $0.03 \mathrm{mg} / \mathrm{L}$ と定めている ${ }^{4)}$ 。わが国においても，1998年 に水道水質の監視項目としてUが追加され，2003年の見直しにより 水質管理目標設定項目（目標值：0.002 $\mathrm{mg} / \mathrm{L}$ ) に設定されている ${ }^{5)}$ 。 また，2004年には，水質污濁に係る人の健康に関する環境基準等に おける要監視項目（指針值：0.002 mg/L) として U が追加され ${ }^{6}$, 水質污濁の未然防止のためのモニタリングの対象となっている。 一方, 我が国の農耕地土壤は, 原野, 非耕地あるいは森林の土壤 改変禁止4.0国際]ライセンスの下に提供されています。
よりもU 濃度が高い傾向にあることが, 国内各地から採取した土壤 を対象に行われた調査において明らかにされており, その原因とし て農業生産の場面で広く用いられているリン酸質肥料の施用による 影響が指摘されている ${ }^{7-9)}$ 。リン酸質肥料中には, その原材料である リン鉱石に由来するUが副次的成分として含まれていることが知ら れており ${ }^{10-14)}$, リン酸質肥料の過剩施用による土䁃への $U$ 蓄積の可

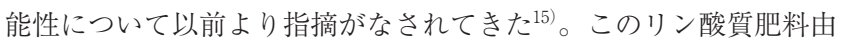
来 Uの土壤蓄積については，61年間, 継続的に化学肥料の施用が実 施された実験围場（長期連用試験围場）における調査でも, その可 能性が認められている ${ }^{16)}$ 。日本は世界でも有数のリン酸質肥料の消 費国であり, その農地面積当たりの消費量は世界でも突出してい る ${ }^{17)}$ 。かつては, リン酸肥沃度の低い農耕地土壤が広く存在し, リ ン酸質肥料の施用による積極的な土畩改良が進められてきたが, 最 近では，その長期にわたる継続的な施用により，作物に吸収されず に残存したリン酸が土壤に過剩蓄積している戋場が多く存在してい る状況にある ${ }^{18)}$ 。例えば, 1979年から1997年にかけて実施されてき た土壌環境基礎調査によれば, 土壤中の可給態リン酸 $(0.001 \mathrm{~mol} /$ $\mathrm{L}$ 硫酸可溶性リン酸) が, 地力増進基本指針に基づく改善目標值を 
超過している围場が，普通畑では17\%程度，野菜畑では $47 \%$ を占め るに至っていることが示されている ${ }^{19)}$ 。このような状況下に拈いて， 上述のようなリン酸質肥料に由来する U の土壤蓄積が，わが国の農 耕地土䁃において広く発生している可能性は十分に考えられる。農 耕地から河川等への土壤の流出は頻繁に観察される現象であり, 周 辺環境への影響を評価する上でも農耕地におけるUの土壤蓄積の実 態を把握することは重要であると考える。しかしながら，実際に農 業生産活動が行われている地域の農耕地を対象に土壤中 U 濃度を調 査した研究報告は少なく，それらに関する知見は限定的である。

土壤中 Uの天然賦活量は土壤母材によって異なることが予想され る ${ }^{20)}$ 。したがって, 農耕地における土壤蓄積の状況を検証するため には，同一母材から生成したと考えられる土壇，すなわち，同一土 壤型の土壤が分布する地域内において調査を行うことが望ましい。 本研究では, 農耕地土壤として, 同一土壤型の土壤が分布する特定 の地域内の営利栽培が行われている生産者戋場から採取した土壤に ついて，その土壤中 U 濃度を明らかにするとともに，同地域内の非 耕地土壤のそれとを互いに比較することで農耕地に扔けるU 蓄積の 実態について検証を行った。また，土壤中の U 濃度とリン（P）濃 度との関係からリン酸質肥料の影響について考察を行うとともに, 各種の化学肥料や堆肥に含まれるU 濃度の分析を行い, それらの施 用量を基に肥料由来 Uの土壤負荷量について推定を試みた。

\section{2. 材料および方法}

\section{1 土壤試料}

鹿児島県内の 4 地域, 伊佐地域 (伊佐市), 長島地域 (出水郡), 南薩地域（南九州市）および大隅地域（鹿屋, 志布志市および曾於 郡）から採取した耕地土壤83点および非耕地土壤25点を分析に供し た（Table 1)。耕地土䁃は農作物の営利栽培が行われている生産者 圃場から採取した。非耕地土壤は少なくとも現在において, 作物栽 培が行われておらず，農業生産活動の影響を受けていない土地，す なわち，ススキ，ヨシなどの草本類が群生する荒地，十分な管理が なされていない雑木林，スギが植栽された林地，人の侵入が少ない 公園や神社境内の緑地などから採取した。耕地土壤は2012年から 2013年にかけて各々の戋場において作物が栽培されていない時期に, 非耕地土壤は2014年 4 月にそれぞれ採取した。土壤はステンレス製 の移植ごてを用いて, 表層から $15 \mathrm{~cm}$ の深さまでを採取し, ポリエ チレン袋に詰めて運搬した。採取した土壤は室温下で風乾させた後, $2 \mathrm{~mm}$ のるいに通したものを分析試料とした。なお，包括的土壤 分類 (第 1 次試案 $)^{21)}$ によれば, 伊佐地域の試料は低地土大群, 長 島地域の試料は赤黄色土大群, 南薩および大隅地域の試料は黒ボク 土大群の土壤型にそれぞれ分類される土壤であった。

\section{2 化学肥料および堆肥試料}

化学肥料として, 窒素質肥料である硫酸アンモニア (硫安),リン 酸質肥料である過リン酸石灰, 苦土重焼リンおよび熔成リン肥（熔 リン), カリ質肥料である塩化カリウム（塩加），石灰質肥料（石灰 質資材）として炭酸苦土石灰を各 1 点ずつ分析に供した。いずれも 鹿児島県内に流通し，作物栽培に利用されているものを入手した。 一方，堆肥として，家畜排せつ物に副資材としておがくず，バーク などを混合して製造された家畜ふん堆肥 3 点と下水污泥を主体とし て製造された下水污泥堆肥 1 点を分析に供した。いずれも鹿児島県 内で市販されていたものである。化学肥料は梱包袋から取り出した そのままの状態のもの, 堆肥は $80^{\circ} \mathrm{C}$ の恒温乾燥器内で約 24 時間乾燥 させたものを，めのう乳鉢掞よびコーヒーミル型粉砕機でそれぞれ 粉砕し分析試料とした。

\section{3 分析方法}

土壤, 化学肥料および堆肥試料からの $\mathrm{U}$ および $\mathrm{P} の$ 抽出は, 硝 酸・過塩素酸による湿式分解法によって行った。すなわち, 試料を トールビーカーに取り, 硝酸および過塩素酸を加え, 時計血でふた をして, ホットプレート上で加熱分解した。次いで, 時計血のふた を取り去り, シロップ状になるまで内容物を加熱濃縮させた。冷却 後, $1 \mathrm{~mol} / \mathrm{L}$ 塩酸拈よび熱水を加えて内容物を溶解させた後, メ久 フラスコ中にろ別し， $100 \mathrm{~mL}$ に定容した。なお，ケイ酸塩鉱物中に

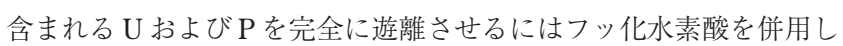
て分解を行うべきであるが, 本研究では実験環境の都合上これを使 用していない。したがって, これらの一部は溶出されず残留したま まである可能性があり，本法で得られる分析值はケイ酸塩鉱物等を 除いた，比較的容易に風化分解されうる画分に含まれる濃度を表し ているものといえる。Uは, 誘導結合プラズマ質量分析 (ICP-MS) 装置（パーキンエルマー社製 ElanDRC）を用いて測定した。白金 （Pt）を最終濃度 $10 \mu \mathrm{g} / \mathrm{L}$ となるように添加した試料液を ICP-MS 装 置により質量数 $238(\mathrm{U})$ および195 (Pt) の強度を測定し, Pt を内部 標準元素とする内部標準法によってU 濃度を求めた。なお, 非耕地 土壤への $1 \mu \mathrm{g} / \mathrm{g}$ 相当量の $\mathrm{U}$ ( $\mathrm{U}$ 含有硝酸溶液) 添加による 5 併行の 添加回収試験から得られた, 本法の平均 U 回収率は $95.9 \%$, その併 行精度は相対標準偏差として $3.2 \%$ であった。また，操作ブランクの 5 回の繰り返し測定によって得られた標準偏差の 10 倍值 $(10 \sigma)$ から 算出された U の定量下限は $0.03 \mu \mathrm{g} / \mathrm{kg}$ であった。Pはバナドモリ ブデン酸アンモニウム吸光光度法によって測定した ${ }^{22)}$ 。U および $\mathrm{P}$ 濃度は, 土壤, 化学肥料および堆肥試料のいずれも乾燥重量あたり の值で示した。

Table 1 Basic information of soil sampling sites

\begin{tabular}{|c|c|c|c|}
\hline \multirow{2}{*}{ Study area } & \multirow{2}{*}{ Soil type } & \multicolumn{2}{|c|}{ Number of soil samples and Land use } \\
\hline & & Agricultural soil (AS) & Non-Agricultural soil (NAS) \\
\hline Isa area & Lowland soils & $\begin{array}{c}13 \\
\text { Paddy field } \\
\text { (paddy rice) }\end{array}$ & $\begin{array}{c}\text { Waste grassland etc. } \\
\text { W }\end{array}$ \\
\hline Nagashima area & Red yellow soils & $\begin{array}{c}15 \\
\text { Upland field } \\
\text { (potato, sweet potato etc.) } \\
\end{array}$ & $\begin{array}{c}5 \\
\text { Waste grassland, Coppice forest etc. }\end{array}$ \\
\hline Nansatsu area & Andosols & $\begin{array}{c}24 \\
\text { Upland field } \\
\text { (sweet potato, leafy vegetable etc.) }\end{array}$ & $\begin{array}{c}6 \\
\text { Waste grassland, Coppice forest etc. }\end{array}$ \\
\hline Osumi area & Andosols & $\begin{array}{c}31 \\
\text { Upland field } \\
\text { (sweet potato, forage crop etc.) }\end{array}$ & $\begin{array}{c}7 \\
\text { Coppice forest, Wood land etc. }\end{array}$ \\
\hline
\end{tabular}




\section{3. 結果及び考察}

\section{1 農耕地土壤の U 濃度とその負荷源}

4 地域から採取した土壤試料の U 濃度は, 伊佐地域が 0.55 3.01 (1.56) $\mu \mathrm{g} / \mathrm{g}$, 長島地域が $0.40 \sim 2.85(1.56) \mu \mathrm{g} / \mathrm{g}$, 南薩地域が $0.40 \sim 2.70(1.34) \mu \mathrm{g} / \mathrm{g}$, 大隅地域が $0.31 \sim 2.39(1.42) \mu \mathrm{g} / \mathrm{g}$ の範 囲（括弧内は中央值）にあった。地域によって土䁃型が異なる，す なわち, 伊佐地域は低地土, 長島地域は赤黄色土, 南薩及び大隅地 域は黒ボク土であるが，地域間で U 濃度の分布に統計的な有意差は 認めらなかった（Kruskal-Wallis 検定, $\mathrm{p}>0.05) 。$

土壤中 $\mathrm{U}$ 濃度は, 各地域内に扔いて, 非耕地と農耕地の間で差異 が認められた (Fig. 1)。各地域の土壤中 U 濃度を非耕地, 農耕地の 順に示すと, 伊佐地域が $0.55 \sim 1.01(0.65) \mu \mathrm{g} / \mathrm{g}, 1.00 \sim 3.01$ $(1.96) \mu \mathrm{g} / \mathrm{g}$ ，長島地域が $0.40 \sim 1.04(0.77) \mu \mathrm{g} / \mathrm{g}, \quad 0.48 \sim 2.85$ $(1.93) \mu \mathrm{g} / \mathrm{g}$, 南薩地域が $0.40 \sim 1.24(0.55) \mu \mathrm{g} / \mathrm{g}, 1.13 \sim 2.70$ (1.63) $\mu \mathrm{g} / \mathrm{g}$, 大隅地域が $0.31 \sim 1.01(0.63) \mu \mathrm{g} / \mathrm{g}, 1.08 \sim 2.39$ (1.52) $\mu \mathrm{g} / \mathrm{g}$ の範囲（括弧内は中央值）にあり，いずれの地域にお いても農耕地の方が非耕地よりも分布範囲が高い傾向にあった (Mann-Whitneyの $\mathrm{U}$ 検定, $\mathrm{p}<0.05$ )。このように, 農耕地の土壤中 U 濃度が非耕地のそれよりも高い傾向にあることは，これまでも Yoshida $ら^{7)}$ およびTakeda $ら^{8)}$ によって指摘されてきた。例えば, 日本全国から採取された土壤試料について, 森林をはじめとする非 農耕地（22試料）の土壤中 $\mathrm{U}$ 濃度の平均值は $1.4 \mu \mathrm{g} \mathrm{g}^{-1}$ であったの
に対し, 水田および畑地などの農耕地（33試料）の平均值は $2.7 \mu \mathrm{g}$ $\mathrm{g}^{-1}$ であったことが示されている ${ }^{8)}$ 。本研究の結果は, これらの報告 を支持するものであった。なお，土壤中 U の天然賦存量は土壤母材 によって差異の生じる可能性が考えられる ${ }^{20)}$ 。本研究ではそれぞれ 特定の地域内において土壤型が同じ土壤，すなわち同一の土壤母材 から生成された土壤を試料とし，それぞれの地域毎に比較検証を 行ったことから, 土畩母材の違いによる影響は無視できるものと考 える。

一方, $\mathrm{U}$ 濃度と同様に, 4 地域から採取した土壤の $\mathrm{P}$ 濃度も非耕 地と農耕地の間で明瞭な差異が認められた（Fig. 2)。各地域の土潩 中 $\mathrm{P}$ 濃度を非耕地, 農耕地の順にそれぞれ示すと, 伊佐地域が $0.25 \sim 0.60(0.44) \mathrm{mg} / \mathrm{g}, 1.00 \sim 3.23(2.10) \mathrm{mg} / \mathrm{g}$, 長島地域が $0.22 \sim 0.76(0.34) \mathrm{mg} / \mathrm{g}, \quad 0.91 \sim 5.03(2.74) \mathrm{mg} / \mathrm{g}$, 南薩地域が $0.76 \sim 1.19(0.89) \mathrm{mg} / \mathrm{g}, \quad 1.55 \sim 6.15(2.40) \mathrm{mg} / \mathrm{g}$, 大隅地域が $0.59 \sim 1.00(0.71) \mathrm{mg} / \mathrm{g}, \quad 0.86 \sim 4.95(2.29) \mathrm{mg} / \mathrm{g}$ の範囲（括弧内 は中央值）にあり，いずれの地域も農耕地の方が非耕地よりも分布 範囲が高い傾向にあった（Mann-WhitneyのU 検定， $\mathrm{p}<0.05 ）$ 。農 耕地における主要な $\mathrm{P}$ 負荷源は, 作物生産において利用される化学 肥料や堆肥などであり，日本国内では，それらの長年にわたる継続 的な土壤施用が残留 $\mathrm{P}$ 成分の土壤蓄積を招いていることが報告され ている ${ }^{18,19)}$ 。本研究で示された農耕地土壤における高い $\mathrm{P}$ 濃度は, 本調査地域の農耕地においても化学肥料や堆肥の継続的な土壤施用 が行われてきたこと，また，それにより P成分の土壤残留が生じて
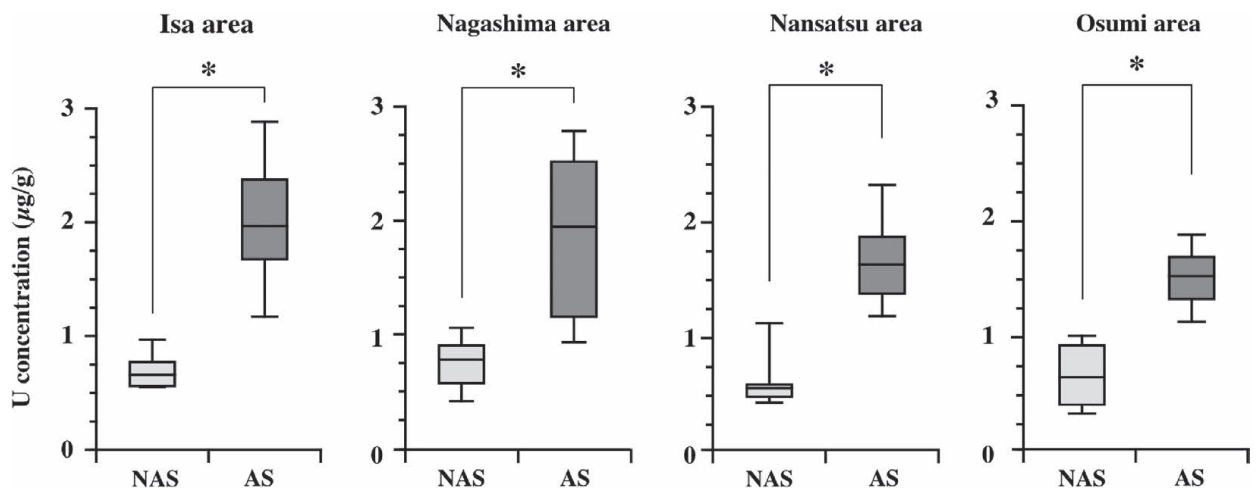

Fig. 1 Uranium (U) concentrations of the agricultural soils (AS) and the non-agricultural soils (NAS) sampled from Isa, Nagashima, Nansatsu, and Osumi area in Kagoshima, Japan

The median is shown as solid line, while the box shows the $25-75$ percentile range. Whiskers extend to $10-90$ percentile. Asterisks $(*)$ indicate significant differences at $\mathrm{P}<0.05$ (by Mann-Whitney U-test).
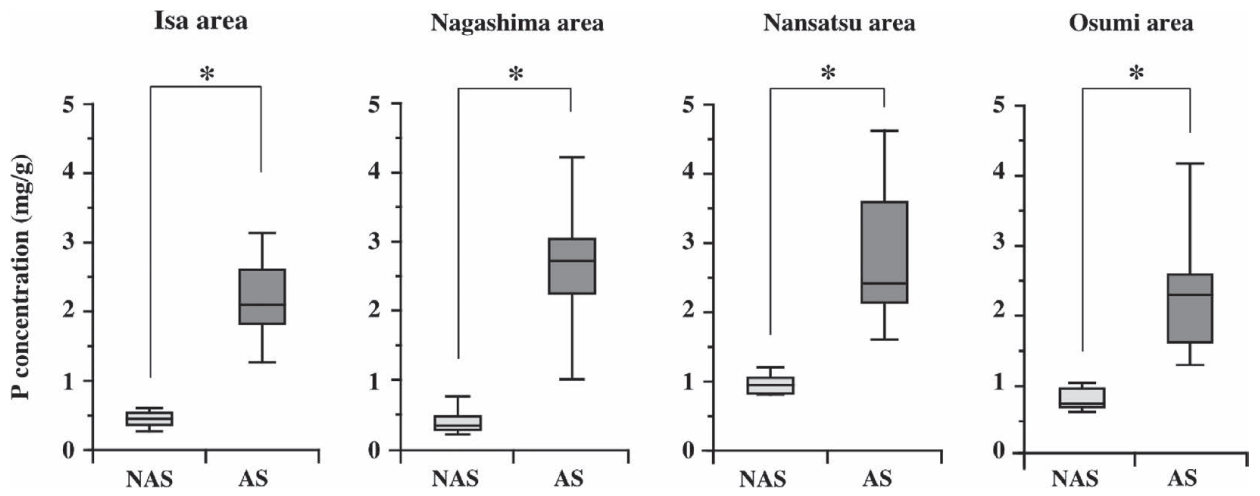

Fig. 2 Phosphorus (P) concentrations of the agricultural soils (AS) and the non-agricultural soils (NAS) sampled from Isa, Nagashima, Nansatsu, and Osumi area in Kagoshima, Japan

The median is shown as solid line, while the box shows the 25-75 percentile range. Whiskers extend to 10-90 percentile. Asterisks $(*)$ indicate significant differences at $\mathrm{P}<0.05$ (by Mann-Whitney U-test). 
いることを示唆していると考えられる。

ところで，土䁃へ $\mathrm{P}$ を供給する主要な肥料であるリン酸質肥料は, 原材料であるリン鉱石に由来するUを副次的成分として含有してお $り^{10-14)}$, 農耕地に扔ける主要な U 負荷源となり得ることが指摘され ている ${ }^{15)}$ 。Fig. 3 は，供試土壤の P 濃度と U 濃度との関係について それぞれ地域別に示したものである。P 濃度とU 濃度との間には, いずれの地域においても（ただし大隅地域はやや弱いが）正の相関 (Spearman の順位相関係数, 伊佐地域 : $r_{s}=0.992$, 長島地域 $: r_{s}=$ 0.818 , 南薩地域 : $r_{s}=0.611$, 大隅地域 : $\left.r_{s}=0.321\right)$ が認められた。 この関係性は, 化学肥料や堆肥の継続的な土壤施用によって土壌中 $\mathrm{P}$ 濃度が高まっている戋場では U 濃度も高まっていることを示して おり, 以前よりその可能性が指摘されてきた, リン酸質肥料に由来 するUの土壤蓄積が本調査地域の農耕地において発生していること を裏付ける結果であるといえる。

なお, Fig. 3 から見て取れるように, P 濃度と $\mathrm{U}$ 濃度との間の回 帰直線の傾きは地域間で違いが認められ, 伊佐 $\left(7.28 \times 10^{-4}\right)$, 長島 $\left(5.04 \times 10^{-4}\right)$, 南薩 $\left(3.87 \times 10^{-4}\right)$, 大隅 $\left(1.26 \times 10^{-4}\right)$ の順に傾きが 小さくなる傾向にあった。このような地域間での傾きの違いは, 後
述のように，家畜ふん堆肥施用量の差異などが反映されている可能 性が考えられる。すなわち, 家畜ふん堆肥の施用量が多いほど土壤 $\mathrm{P}-\mathrm{U}$ 濃度図における傾きが小さくなることが予想される。現時点 に扔いて, 各地域に扔ける農耕地の利用履歴や詳細な肥料資材の施 用量等に関する情報は収集できておらず, ここで十分な考察を行う ことはできないが，この予想に基づけば，傾きが小さい傾向にあっ た南薩および大隅地域は，伊佐および長島地域と比較して家畜ふん 堆肥の投入量が多い傾向にあると考えられる。伊佐地域は水稲, 長 島地域はジャガイモが主要な栽培作物であるのに対し, 南薩扔よび 大隅地域は飼料作物, 葉菜類などの露地野菜が特徵的に広く栽培さ れており,このような栽培作物の違いが家畜ふん堆肥の利用状況に 関連しているのかもしれない。

ここで, 農耕地と非農耕地の $\mathrm{U}$ 存在量の差分をもとに, 各調査地 域における Uの土壤蓄積量の推定を試みる。非耕地土壤の $\mathrm{U}$ 濃度の 中央值は, 伊佐地域が $0.65 \mu \mathrm{g} / \mathrm{g}$, 長島地域が $0.77 \mu \mathrm{g} / \mathrm{g}$, 南薩地域 が $0.55 \mu \mathrm{g} / \mathrm{g}$, 大隅地域が $0.63 \mu \mathrm{g} / \mathrm{g}$ であった。これらの值をそれ ぞれの地域の土壤中 U の天然賦存量とみなし, 農耕地土壤における 存在量との差を $\mathrm{U}$ 蓄積量として算出した。なお, 土䁃中の $\mathrm{U}$ 存在量
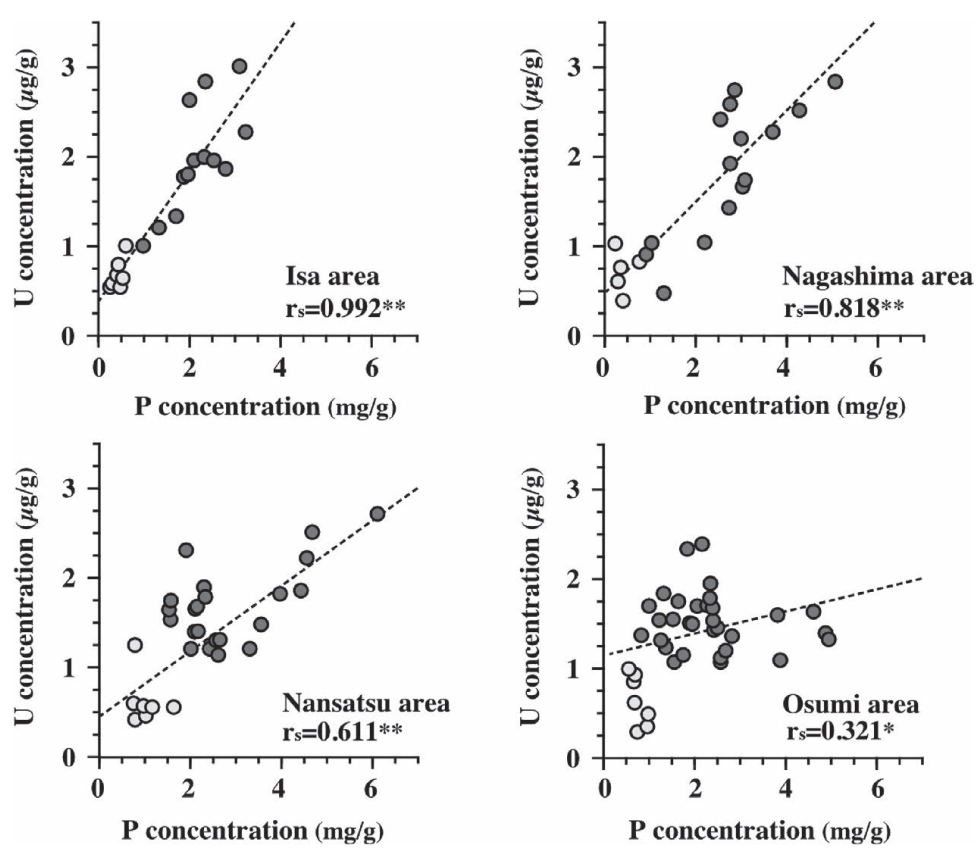

Fig.3 Relationship between phosphorus (P) concentrations and uranium (U) concentrations of the agricultural soils and the non-agricultural soils

Open circles and filled circles represent agricultural soils and non-agricultural soils. Single (*) and double asterisks $(* *)$ indicate significant correlations at $5 \%$ and $1 \%$ levels, respectively.

Table 2 Amounts of uranium (U) enriched in the agricultural soils $(0-15 \mathrm{~cm}$ depth) calculated from comparison with the non-agricultural soils

\begin{tabular}{|c|c|c|c|c|c|c|}
\hline & \multicolumn{2}{|c|}{$\begin{array}{l}\text { U concentration in soil } \\
(\mu \mathrm{g} / \mathrm{g})\end{array}$} & \multirow{2}{*}{$\begin{array}{l}\text { Bulk density } \\
\left(\mathrm{Mg} / \mathrm{m}^{3}\right)\end{array}$} & \multicolumn{2}{|c|}{$\begin{array}{c}\text { Amount of } U \text { in soil } \\
\left(\mathrm{mg} / \mathrm{m}^{2} \text { to a depth of } 15 \mathrm{~cm}\right)\end{array}$} & \multirow{2}{*}{$\begin{array}{l}\text { Amount of } \mathrm{U} \text { enriched } \\
\text { in agricultural soil } \\
\left(\mathrm{mg} / \mathrm{m}^{2} \text { to a depth of } 15 \mathrm{~cm}\right)\end{array}$} \\
\hline & NAS (median) & AS (range) & & NAS & $\mathrm{AS}$ & \\
\hline Isa area & 0.65 & $1.00-3.01$ & 0.9 & 88 & $135-406$ & $47-318$ \\
\hline Nagashima area & 0.77 & $0.92-2.85^{*}$ & 1.1 & 127 & $152-470$ & $25-343$ \\
\hline Nansatsu area & 0.55 & $1.13-2.70$ & 0.7 & 58 & 119-284 & $61-226$ \\
\hline Osumi area & 0.63 & $1.08-2.39$ & 0.7 & 66 & $113-251$ & $47-185$ \\
\hline
\end{tabular}

* exclude one site where the $\mathrm{U}$ concentration were lower than that of median of non-agricultural soils 
を求めるにあたり, 低地土 (伊佐地域), 赤黄色土 (長島地域), 黒 ボク土（南薩および大隅地域）の容積重をそれぞれ $0.9 \times 10^{3} \mathrm{~kg} / \mathrm{m}^{3}$, $1.1 \times 10^{3} \mathrm{~kg} / \mathrm{m}^{3}, \quad 0.7 \times 10^{3} \mathrm{~kg} / \mathrm{m}^{3}$ として算出した。その結果，非耕 地土壤の中央值よりも濃度が低かった長島地域の 1 地点を除けば, Table 2 に示すように, 土壤（深さ $15 \mathrm{~cm}$ ) $1 \mathrm{~m}^{2}$ あたり伊佐地域では 47 318 (177) mg, 長島地域では 25 343 (191) mg, 南薩地域では 61〜226（113） mg，大隅地域では 47〜185（94） mgのUが蓄積して いるとそれぞれ見積もられた（括弧内は中央值）。なお，化学肥料に 由来するUの土壤蓄積量に関して, 1940年から継続的に化学肥料が 施用された実験戋場（長期連用試験戋場）を対象に行われた調査事 例がTakeda らによって報告されている ${ }^{16)}$ 。これによれば, 化学肥 料，堆肥および石灰質資材を連用した試験区では，61年間で 201 $\mathrm{mg} / \mathrm{m}^{2}$ の U が土壤表層に蓄積されたと推定されている。以上に示 した本調査地域の蓄積推定值は, この長期連用試験戋場の調査から 得られた推定值と近い值であるといえる。

\section{2 肥料に由来する農耕地土壤へのU 負荷量の推定}

鹿児島県内で流通している化学肥料および堆肥中の U 濃度の分析 結果を Table 3 に示した。化学肥料中の U 濃度はその種類によって 大きく異なり, 窒素質肥料である硫酸アンモニアおよびカリ質肥料 である塩化カリウムの U 濃度は定量下限 $(0.03 \mu \mathrm{g} / \mathrm{g})$ 未満であっ たのに対し、リン酸質肥料である過リン酸石灰，苦土重焼リンおよ び熔成リン肥には，それぞれ $51.6 \mu \mathrm{g} / \mathrm{g}, 22.2 \mu \mathrm{g} / \mathrm{g}$ および $10.6 \mu \mathrm{g} /$ $\mathrm{g}$ の U を含有していた。また, 土壤酸性矯正に用いられる石灰質資 材である炭酸苦土石灰も $0.45 \mu \mathrm{g} / \mathrm{g}$ の U を含有していた。リン酸質 肥料中の U 濃度については，国内外でいくつかの報告がなされてい る。例えば, 米国で流通している過リン酸石灰中には $60.5^{13)} \mu \mathrm{g} / \mathrm{g}$, 重過リン酸石灰中には $177^{13)} \mu \mathrm{g} / \mathrm{g}$ のUが含まれていたこと, また, 日本国内で流通されているリン酸質肥料については, 過リン酸石灰 中に $31^{16)} ， 74^{10)}, 85^{23)} \mu \mathrm{g} / \mathrm{g}$, 重過リン酸石灰に $268^{23)} \mu \mathrm{g} / \mathrm{g}$, 熔成リ ン肥中に $49^{23)}, 106^{10)} \mu \mathrm{g} / \mathrm{g}$ の Uが含まれていたことが報告されてい る。本研究で得られた過リン酸石灰の U 濃度はこれらの報告值の範 囲内，熔成リン肥の $\mathrm{U}$ 濃度は報告值よりやや低い值を示したが，リ ン鉱石を原材料とするリン酸質肥料はいずれも $10 \mu \mathrm{g} / \mathrm{g}$ を超える $\mathrm{U}$ を含有しており，農耕地におけるUの負荷源となり得ることが示さ れた。

一方, 堆肥中にもわずかながらUが含まれており, その濃度は家 畜ふん堆肥が $0.88 \sim 1.07 \mu \mathrm{g} / \mathrm{g}$, 下水污泥堆肥が $1.56 \mu \mathrm{g} / \mathrm{g}$ であっ た。堆肥中の U 濃度に関する報告は限られているが, 国内に打ける 調査例として, 稲わら由来の堆肥に $0.2^{16)} \mu \mathrm{g} / \mathrm{g}$ の U が, 米国にお ける調査例として, 家畜ふん由来の堆肥に $0.1 \sim 3.5$ (中央值： $1.4)^{13)} \mu \mathrm{g} / \mathrm{g}$ の Uが含まれていたと報告されている。

なお, リン酸質肥料, 家畜ふん堆肥および下水污泥堆肥に Uが含 まれることが確認されたが，Pに対するUの濃度比（U/P 比）はそ れぞれの肥料資材で大きく異なった。例えば，過リン酸石灰の U/P 比は6.1×10-4であるのに対して家畜ふん堆肥では $0.3 \times 10^{-4} \sim 0.9 \times$ $10^{-4}$ 程度であった。このことは, 肥料資材による土壤への $\mathrm{P}$ 投入量 が同程度であっても，U 負荷量は両者で大きく異なることを示唆し ており，先に示した土壤中 $\mathrm{P}$ 濃度と $\mathrm{U}$ 濃度との関係（Fig. 3）にお いて, 家畜ふん堆肥の投入量が相対的に多い地域では $\mathrm{P}$ 濃度と $\mathrm{U}$ 濃 度との間の傾きが小さくなることが予想される。例えば, 大隅地域 は国内有数の畜産集中地域であり, 家畜ふん堆肥投入量の多い圃場 の存在が想定される。Fig. 3 を見ると, この大隅地域は他地域より も明暸に傾きが小さく, 土壤中 $\mathrm{P}$ 濃度が $4 \mathrm{mg} / \mathrm{g}$ を超過していても 土壤中 $\mathrm{U}$ 濃度は $2 \mu \mathrm{g} / \mathrm{g}$ に達していない戋場も認められる。このこ とは，上述の予想を支持しているように思われる。
ここで, 本研究によって示されたリン酸質肥料㧍よび堆肥中の $\mathrm{U}$ 濃度を基に， 1 作あたりに負荷される肥料由来 $\mathrm{U}$ 量について推定を 試みた。肥料の施用量は生産者によって異なることが予想されるが,

Table 3 Uranium (U) and phosphorus (P) concentrations of commercially available chemical fertilizers and composts

\begin{tabular}{|c|c|c|c|}
\hline & \multicolumn{2}{|c|}{ Concentration } & \multirow{2}{*}{$\begin{array}{c}\mathrm{U} / \mathrm{P} \\
\left(\times 10^{-4}\right)\end{array}$} \\
\hline & $\begin{array}{c}\mathrm{U} \\
(\mu \mathrm{g} / \mathrm{g})\end{array}$ & $\begin{array}{c}\mathrm{P} \\
(\mathrm{mg} / \mathrm{g}) \\
\end{array}$ & \\
\hline \multicolumn{4}{|l|}{ Chemical fertilizers } \\
\hline $\begin{array}{l}\text { Nitrogen fertilizer } \\
\text { ammonium sulfate }\end{array}$ & $<0.03$ & $<0.4$ & - \\
\hline \multicolumn{4}{|l|}{ Phosphate fertilizer } \\
\hline superphosphate & 51.6 & 85.2 & 6.1 \\
\hline magnesium multi-phosphate & 22.2 & 149 & 1.5 \\
\hline fused magnesium phosphate & 10.6 & 74.1 & 1.4 \\
\hline \multicolumn{3}{|l|}{ Potassium fertilizer } & - \\
\hline $\begin{array}{l}\text { Liming material } \\
\text { calcium magnesium carbonate }\end{array}$ & 0.45 & $<0.4$ & - \\
\hline \multicolumn{4}{|l|}{ Composts } \\
\hline animal waste compost $\mathrm{A}$ & 0.90 & 9.6 & 0.9 \\
\hline animal waste compost $B$ & 1.07 & 38.9 & 0.3 \\
\hline animal waste compost $\mathrm{C}$ & 0.88 & 14.7 & 0.6 \\
\hline sewage sludge compost & 1.56 & 12.5 & 1.2 \\
\hline
\end{tabular}

Table 4 Estimated amounts of U input per cropping system added from fertilizers

\begin{tabular}{|c|c|c|c|}
\hline & $\begin{array}{c}\text { Standard } \\
\text { application } \\
\text { rate } \\
\left(\mathrm{g} / \mathrm{m}^{2}\right) \\
\end{array}$ & $\begin{array}{c}\mathrm{U} \\
\text { concentration } \\
(\mu \mathrm{g} / \mathrm{g}) \\
\end{array}$ & $\begin{array}{c}\text { Amount of } \\
\mathrm{U} \text { input } \\
\left(\mathrm{mg} / \mathrm{m}^{2}\right) \\
\end{array}$ \\
\hline \multicolumn{4}{|l|}{ Rice } \\
\hline Animal waste compost & 1000 & 0.9 & 0.9 \\
\hline Superphosphate & $34-40$ & 51.6 & $1.8-2.1$ \\
\hline sum & & & $2.7-3.0$ \\
\hline \multicolumn{4}{|l|}{ Potato } \\
\hline Animal waste compost & $1000-1500$ & 0.9 & $0.9-1.4$ \\
\hline Superphosphate & 74 & 51.6 & 3.8 \\
\hline sum & & & $4.7-5.2$ \\
\hline \multicolumn{4}{|c|}{ Sweet potato (for starch and alcohol production) } \\
\hline Animal waste compost & 1000 & 0.9 & 0.9 \\
\hline Superphosphate & 69 & 51.6 & 3.6 \\
\hline sum & & & 4.5 \\
\hline \multicolumn{4}{|l|}{ Cabbage } \\
\hline Animal waste compost & 2000 & 0.9 & 1.8 \\
\hline Superphosphate & 86 & 51.6 & 4.4 \\
\hline sum & & & 6.2 \\
\hline \multicolumn{4}{|l|}{ Chinese cabbage } \\
\hline Animal waste compost & 2000 & 0.9 & 1.8 \\
\hline Superphosphate & $131-143$ & 51.6 & $6.8-7.4$ \\
\hline sum & & & $8.6-9.2$ \\
\hline \multicolumn{4}{|l|}{ Forage crop (gramineous) } \\
\hline Animal waste compost & 2000 & 0.9 & 1.8 \\
\hline Superphosphate & $86-114$ & 51.6 & $3.6-5.9$ \\
\hline sum & & & $5.4-7.7$ \\
\hline
\end{tabular}


個々の生産者の施用実態を把握することは極めて困難である。した がって, ここでは鹿児島県における作物毎の化学肥料および堆肥の 適正施用量 (標準施肥量) として示されている施肥基準 ${ }^{24)}$ を参考と して推定を試みた。なお，リン酸質肥料は過リン酸石灰（リン酸含 有率 $17.5 \%, \mathrm{U}$ 濃度 $51.6 \mu \mathrm{g} / \mathrm{g}$ として算出）を，堆肥は家畜ふん堆 肥（U 濃度 $0.9 \mu \mathrm{g} / \mathrm{g}$ として算出）をそれぞれ施用したものとした。 Table 4 は, 当地域で広く生産されている, 水稲 (普通期), ジャガ イモ, 加工用サッマイモ, キャベッ, 八クサイおよび飼料作物（イ ネ科牧草等)の 1 作あたりの肥料由来 U 負荷量の推定值を表したも のである。ここに示されるように，推定された U 負荷量は，最も低 く見積もられた水稲栽培で $2.7 \sim 3.0 \mathrm{mg} / \mathrm{m}^{2}$, 最も高く見積もられ たハクサイ栽培で 8.6 9.2 $\mathrm{mg} / \mathrm{m}^{2}$ であった。このように, 1 作あ たりの肥料由来 U 負荷量は栽培作物によって大きく異なり，キャべ ツ, 八クサイなどの葉菜類や飼料作物の栽培に扔ける U 負荷量は, 水稲と比較して大きいことが示された。

注目されるのは, 家畜ふん堆肥に由来するU 負荷量である。家畜 ふん堆肥に含まれる $\mathrm{U} は 0.9 \mu \mathrm{g} / \mathrm{g}$ 程度と濃度は低いものの, 施用 量は一般にリン酸質肥料よりもはるかに多いことから，そのU負荷 量は総負荷量の17〜33\%に達することが示された。これまで，農耕 地土壤へのU負荷源として, 家畜ふん堆肥はほとんど考慮されてこ なかったが，その施用量が多い場合においては重要な負荷源となり 得ると考えられる。なお，わが国で流通する家畜ふん堆肥の U 濃度 に関する情報は極めて限られている。家畜ふん堆肥にUが含有する 原因は不明であり，そもそも主原料である家畜ふん尿および堆肥化 の副資材であるおがくず，バーク等にそれぞれどの程度のUが含有 しているのかについても明らかではない。今後，これらの調査およ び解明が必要である。

ところで, 水田に負荷されたリン酸質肥料由来Uは，そのほぼ全 量が土壌に吸着保持されることが吸着モデル実験および実験戋場に 扮ける収支調査によって明らかにされている ${ }^{23)}$ 。もし仮に，ここで 推定された水稲栽培における肥料由来 U 負荷量のすべてが土壤に吸 着保持されたと仮定すれば， 60 年で $168 \sim 186 \mathrm{mg} / \mathrm{m}^{2}$ のUが土壤へ 蓄積されたものと計算される ( 1 年 1 作の場合)。これは農耕地と非 農耕地の差を基に算出された，水稲栽培地域である伊佐地域の $\mathrm{U}$ 蓄 積量の中央值 $\left(177 \mathrm{mg} / \mathrm{m}^{2}\right)$ と近い值を示しており, 肥料が農耕地 における主要な U 負荷源となっていることを裏付けるものであると 考える。なお，現在（2020年）より60年前にあたる1960年に㧍ける 本地域の水稲栽培での肥料利用実態は明らかではないが, 西尾の報 告 ${ }^{17)}$ によれば，わが国においてこの当時には，少なくとも推定の際 に用いたリン酸質肥料の施肥基準 $\left(6 \sim 7 \mathrm{~g} / \mathrm{m}^{2}\right)$ に相当するリン酸 質肥料が施用されていたことが示されている。

以上のように, 今回調査を行った地域の農耕地では, 肥料に由来 するものと推察されるUの土壤蓄積が認められることが明らかと なった。現在，我が国に扔いて，Uによる一次農産物の污染は報告 されておらず，食品衛生法でもUに関する基準值等は設定されてい ない。現時点における農耕地土壤の U 濃度が経根吸収による農産物 のU污染を引き起こすレべルにまで達しているとは考えられないが, 将来に打けるさらなるU 濃度の増加は食品の安全性の観点からも望 ましくない。適正な肥料の利用による肥料由来 U の負荷低減が必要 である。現在，国内では農耕地土壤へのリン酸の蓄積を抑制させる ための新たな施肥基準の策定が進められ ${ }^{25-27)}$, 土壤のリン酸濃度レ ベルに応じてリン酸質肥料の施用量を減じるといった取り組みが農 業生産現場へ普及しつつある。このような肥料施用量の適正化は, 肥料成分であるリン酸だけでなく副次的成分であるUの負荷低減に も有効な取り組みであると考える。

\section{要 約}

鹿児島県内の 4 地域（伊佐, 長島, 南薩および大隅地域）の農耕 地土壤および非耕地の土壤中ウラン（U）濃度を測定した。いずれ の地域においても, 農耕地土壤の U 濃度は, 非耕地のそれよりも高 い傾向にあった。また，土壤中の $\mathrm{P}$ 濃度と $\mathrm{U}$ 濃度との間には正の相 関が認められ, リン酸質肥料の継続的な土壤施用とUの土壤蓄積と の関連性が示唆された。非農耕地との比較から算出した伊佐，長島， 南薩掞よび大隅地域の農耕地土壤（表層 0 15 cm）に扔ける U 蓄 積量は，それぞれ47〜 318，25～343，61～226抢よび 47〜 $185 \mathrm{mg}$ / $\mathrm{m}^{2}$ であると推定され, 鹿児島県内の農耕地土壤において U の蓄積 が生じていることが明らかとなった。一方，本地域で流通している 過リン酸石灰, 苦土重焼リン, 熔成リン肥, 家畜ふん堆肥および下 水污泥堆肥には，それぞれ51.6，22.2，10.6，0.88１.07および $1.56 \mu \mathrm{g} / \mathrm{g}$ のUが含有しており, これらの肥料資材は農耕地におけ るU 負荷源となり得ることが示された。各作物の肥料施肥量を基に した計算によれば, 1 作当たり水稲では $2.7 \sim 3.0 \mathrm{mg} / \mathrm{m}^{2}$, 八クサ イでは 8.6 9.2 $\mathrm{mg} / \mathrm{m}^{2}$ の U が肥料から負荷されると推定され， 1 作あたりの肥料由来 U 負荷量は栽培作物によって大きく異なること が示された。

\section{文 献}

1) Taylor, D. and Taylor, S.: Environmental uranium and human health. Rev. Environ. Health., 12, 147-157 (1997)

2) Domingo, J.: Reproductive and developmental toxicity of natural and depleted uranium: A review. Reprod. Toxicol., 15, 603-609 (2001)

3) Patočka, J.: Human health and environmental uranium. Mil. Med. Sci. Lett., 83, 120-131 (2014)

4) World Health Organization:"Guidelines for Drinking-water Quality" 4th Edition, p. 541, Geneva (2011)

5）厚生労働省：水質基準の見直しにおける検討概要 I. 健康に関 する項目 1. 無機物質 (1) 金属類 11102 ウラン, https://www. mhlw.go.jp/topics/bukyoku/kenkou/suido/kijun/dl/moku02. pdf, 2020年 3 月 12 日現在

6）環境省：水質污濁に係る人の健康の保護に関する環境基準等の施 行等について (通知), https://www.env.go.jp/hourei/05/000107. $\mathrm{html}, 2020$ 年 3 月12日現在

7) Yoshida, S., Muramatsu, Y., Tagami, K. and Uchida, S.: Concentrations of lanthanide elements, Th, and $\mathrm{U}$ in 77 Japanese surface soils. Environ. Int., 24, 275-286 (1998)

8) Takeda, A., Kimura, K. and Yamasaki, S.: Analysis of 57 elements in Japanese soils, with special reference to soil group and agricultural use. Geoderma, 119, 291-307 (2004)

9）田上恵子, 内田滋夫：U/Th 比を用いたリン鉱石原料のリン酸 肥料施用による農耕地土壤中ウラン増加割合の推定, Radioisotopes, 55, 71-78 (2006)

10）小村和久, 柳沢美樹男, 桜井次郎, 阪上正信：リン鉱石および リン酸肥料中のウラン, トリウム, カリウム含有量とウラン系 列, トリウム系列各種の放射平衡, Radioisotopes, 34, 529-536 (1985)

11) Hamamo, H., Landsberger, S., Harbottle, G. and Panno, S.: Studies of radioactivity and heavy metals in phosphate fertilizer. $J$. Radioanal. Nucl. Chem. Artic., 194, 331-336 (1995)

12) Raven, K. and Loeppert, R.: Trace element composition of fertilizers and Soil Amendments. J. Environ. Qual., 26, 551-557 
(1997)

13) McBride, M. and Spiers, G.: Trace element content of selected fertilizers and dairy manures as determined by ICP-MS. Commun. Soil Sci. Plant Anal., 32, 139-156 (2001)

14) Yamazaki, I.M. and Geraldo, L.P.: Uranium content in phosphate fertilizers commercially produced in Brazil. Appl. Radiat. Isot., 59, 133-136 (2003)

15) Rothbaum, H., McGaveston, D., Wall, T., Johnston, A. and Mattingly, G.: Uranium accumulation in soils from long-continued applications of superphosphate. J. Soil Sci., 30, 147-153 (1979)

16) Takeda, A., Tsukada, H., Takaku, Y., Hisamatsu, S. and Nanzyo, M.: Accumulation of uranium derived from long-term fertilizer applications in a cultivated Andisol. Sci. Total Environ., 367, 924931 (2006)

17）西尾道德：日本における化学肥料消費の動向と問題点, 日本土 畩肥料学䧱誌，73，219-225（2002）

18）吉池昭夫：農耕地に扔ける施用リン酸の蓄積について, 日本土 壤肥料学䧱誌，54，255-261（1983）

19）小原 洋, 中井 信: 農耕地土壤の可給態リン酸の全国的変動 農耕地土壤の特性変動（II）, 日本土壤肥料学雑誌, 75, 59-67 (2004)
20) Kabata-Pendias, A.: Elements of Group 3 IV Actinides, pp. 158165, "Trace Elements in Soils and Plants" 4th Edition, CRC Press, Boca Raton (2011)

21）小原 洋, 大倉利明, 高田裕介, 神山和則, 前島勇治, 浜崎忠 雄: 包括的土壤分類 第 1 次試案, 農業環境技術研究所報告, 29, 1-73 (2011)

22）関谷宏三：リン酸の比色定量法, pp. 225-229,「土壤養分分析 法」, 土壤養分測定法委員会編, 養賢堂, 東京 (1970)

23）津村昭人, 山崎慎一：水田環境におけるウラン, トリウムおよ びランタノイドの動態, Radioisotopes, 42, 265-272（1993）

24）鹿児島県農政部：「土壤改良及び施肥改善指針（5 訂版)」, pp. 1-112 (2003)

25）新良力也, 伊藤豊彰：水稲作におけるリン酸減肥基本指針の策 定, 日本土壤肥料学雑誌, 87, 462-466（2016）

26）和田 巽, 棚橋寿彦：葉菜類（コマツナ・ホウレンソウ）にお けるリン酸減肥指針の設定, 日本土壤肥料学雑誌，88，129-133 (2016)

27）長友 誠, 上薗一郎, 有村恭平, 森 清文, 古江広治: 黒ボク 畑に抢ける可給態リン酸含量に対応したリン酸施肥, 日本土塞 肥料学雑誌， 88，48-52（2017） 